\title{
Liquidity Risk under The New Basel Global Regulatory Framework
}

\author{
Sviatlana Hlebik ${ }^{1}$ \\ ${ }^{1}$ Ph.D., Catholic University, Milan, Italy; University of Parma, Italy; Crédit Agricole banking group, Italy \\ Correspondence: Sviatlana Hlebik, Crédit Agricole banking group, Mistrali 1, Parma, Italy.
}

Received: September 27, 2017

Accepted: October 26, $2017 \quad$ Available online: October 29, 2017

doi:10.11114/aef.v4i6.2674

URL: https://doi.org/10.11114/aef.v4i6.2674

\begin{abstract}
This paper contributes to understanding liquidity risk and its role in systemic financial crises. It focuses on the new banking regulation Basel III, in particularly on the Liquidity risk ratio that measures long-term liquidity positions of European banks. It emphasizes the importance and the issues relating to the Net Stable Funding Ratio (NSFR) which will become a minimum standard by 1 January 2018. Application at a level of $100 \%$ to credit institutions and systemic investment firms is not however expected before 2020, two years after the date of entry into force of the proposed Regulation. The paper aims to analyze the relationship between NSFR and banking stability, financial markets factors and central bank operations, in order to understand the potential impact of the key components of the new Basel global regulatory framework.
\end{abstract}

Keywords: banks, basel III, net stable funding ratio, liquidity risk, banking regulation

JEL Codes: G21; G28

\section{Introduction}

The theory of financial intermediation highlights two central roles of banks in the economy, the first is liquidity creation, and the second role is risk transformation. Commercial banks take funds in the form of deposits from the public, and provide loans to the businesses, households and other sectors. They thus contribute to economic growth by financing investment and facilitating production through converting liquid liabilities into illiquid assets. In spite of this, however, they can suffer from fragility of their capital structure because of imbalance between liabilities and assets. Furthermore, distress to funding and liquidity crunch are both critical issues in many systemic banking crises. A financial crisis often begins with relatively minor problems which are increased and magnified by lack of liquidity in an already vulnerable system.

In response to the recent global financial crisis, the Basel Committee on Banking Supervision announced a new international regulatory framework for banks. Basel III introduced liquidity regulation for managing liquidity risk in several aspects. It includes the Liquidity Coverage Ratio (LCR), the Net Stable Funding Ratio (NSFR) and liquidity risk monitoring tools that aim to ensure the quantity of high-quality liquid assets that banks will be obliged to hold in order to better manage the maturity mismatch between their assets and liabilities.

The paper is structured as follows. Section 2 presents the literature review, Section 3 discusses the liquidity risk in the recent financial crisis and illustrates some possible liquidity spirals. Section 4 discusses the Basel liquidity regulation and Section 5 presents the empirical analysis of the relationship between NSFR and banking stability, financial markets factors, and central bank operations. Section 6 presents the conclusions.

\section{Literature Review}

Several studies on financial crises have emphasised the importance of liquidity risk. Diamond and Dybvig (2007) discuss liquidity creation as a core function of banks. They develop a model useful to understand bank runs and other types of financial crises, as well as ways of preventing such crises. The reasons why bank assets are illiquid and other reasons that banks help to create liquidity are analyzed in Diamond and Rajan (2005). They argue that bank failures can be contagious. Failures can occur not just as a result of depositor panics or contractual links between banks, but also because bank failures can diminish the common pool of liquidity, thus causing or aggravating aggregate liquidity shortages. This can have serious consequences; contagion of failure or even a total crash of the system.

Some authors such as Persaud (2003) and Hull (2015) make a contribution to defining and understanding "liquidity 
black holes" as situations in the markets "when a price decline causes more market participants to want to sell, driving prices well below where they eventually settle. During the sell-off, liquidity dries up and the asset can be sold only at a fire-sale price". Since a "liquidity black hole" is the analogue of the run outcome in a bank run model, Morris and Shin (2004) provide empirical implications and solutions for the sole trigger point at which the liquidity black hole comes into existence.

With reference to the impact of the new global regulatory framework (Basel III), a preliminary global analysis was carried out by the Basel Committee and one at European level by the European Banking Authority (EBA).

Dietrich et al. (2014) show that larger and faster growing banks active in asset management and investment banking historically were not historically in compliance with net stable funding ratio (NSFR). Many of them began to improve after the onset of the 2008 crisis.

Vazquez \& Federico (2012) measure structural liquidity in bank balance sheets using the Net Stable Funding Ratio (NSFR) proposed in Basel III. They define the impact of the approximated NSFR and bank leverage on the probability of default. They argue that banks with weaker structural liquidity and higher leverage before the global financial crisis were more susceptible to fail. They also note that small banks were more liable to failure on liquidity problems, while large international banks were more likely to fail because of insufficient capital buffers.

The aim of the new Basel III framework is "to improve the banking sector's ability to absorb shocks arising from financial and economic stress" (BCBS 2010), thus to improve financial stability and resilience of financial institutions, preventing bank failures(BCBS 2011).

Hong et al. (2014) calculate the approximate measures of the Basel III LCR and NSFR for US banks. The authors draw up a bank failure model and find that market-wide liquidity risk is significant in predicting bank failure, while idiosyncratic liquidity risk is less important.

There are few studies on the determinants of liquidity risk. Since before Basel III, liquidity risk has been a part of the category of the residual risk, even from a regulatory standpoint. Many economists and researchers thus analyze it as a determinant of other risks, including credit risk (Treepongkaruna et al.2011)

Recent studies have been conducted on the determinants of liquidity in Hungarian commercial banks during the period 2001-2010 (Vodovà, 2013). Vodovà finds that bank liquidity is positively related to capital adequacy of banks, interest rate on loans and bank profitability and negatively related to the size of the bank, interest margin, monetary policy interest rate and the interest rate on interbank transactions.

There are various financial sector mechanisms which can lead to a small shock having a big effect. Krishnamurthy(2010) identifies financial amplification mechanisms which can be activated during a crisis, including leverage, tight credit conditions and limited capital.

\section{Liquidity Risk in the Recent Financial Crisis}

There are many ways of defining the concepts of liquidity and liquidity risk. According to the European Banking Authority (EBA, 2013), liquidity is the "risk that an institution cannot meet its financial obligations, such as payments and collateral needs, as they fall due in the short and medium term, either at all or without incurring unacceptable losses."

Over the past 20 years, financial markets have experienced several liquidity crises. Minor turmoil in financial markets can be amplified by liquidity problems, leading to a major crisis. (For an overview of liquidity crises and liquidity more broadly, see Amihud, Mendelson and Pedersen (2013).

The banking industry faced huge losses during the recent financial crisis, but outright losses from subprime mortgages were relatively small, equivalent to a 2-3 percent fall in U.S. stock prices (IMF, April 2008 Global Financial Stability Report). However, the problems were amplified enormously through liquidity effects, and spread to many other key sectors of the financial system and economy. Once Lehman Brothers began to have financial difficulties with immediate payments, additional losses were incurred that pushed it deeper into insolvency. In another example, Bear Stearns was the fifth largest investment bank in the United States

According to the vigilance inspectors, it exceeded regulatory capital requirements, but its market capitalization deteriorated through the second half of 2007, there were rumors that clients were withdrawing capital from the bank, and it failed in 2008. Likewise, the British Northern Rock requested emergency funding from the Bank of England because it lost the ability to borrow from other banks, could not securitize and had insufficient liquid assets to survive for more than a few weeks. In 2007, the bank received a liquidity support facility from the Bank of England and several months later, in 2008, it was nationalized.

The issues encountered in the interbank market created major problems for banks. They started accumulating liquidity, 
preferring more liquid assets and reducing the periods at which they would lend to other banks. Confidence in the banking system was severely undermined and led to the banks' reluctance to lend to one another, and consequently, unprecedented illiquidity in the interbank markets.

When the banking system comes under strong funding pressure, central banks introduce emergency liquidity operations, and apply non-standard monetary policy measures. The funding system connects banks with other banks, and other financial and non-financial sectors. The failure of one entity to meet its obligations punctually and in full can cause others to be short of liquidity, and create a cascade mechanism with a negative illiquidity effect. In fact the liquidity properties of an asset or an entity are determined by market conditions and by the interrelation between market participants, not only by the features of the asset or entity itself.

\section{Basel Liquidity Regulation}

The financial crisis, in which liquidity shocks at individual institutions led to a systemic crisis in financial markets obliged the Basel Committee on Banking Supervision (BCBS) to re-evaluate and boost guidelines and fundamental principles on which liquidity risk management is based. "Basel III: International Framework for Liquidity Risk Measurement, Standards and Monitoring" is key document published in 2010. It looks at how banks manage risks connected to liquidity funding.

Two new standards were issued by BCBS: the Liquidity Coverage Ratio (LCR) and the Net Stable Funding Ratio (NSFR). They address two complementary sets of issues. LCR "aims to ensure that a bank has an adequate stock of unencumbered high quality liquid assets (HQLA) that consists of cash or assets that can be converted into cash at little or no loss of value in private markets, to meet its liquidity needs for a 30 calendar day liquidity stress scenario" (BIS; 2013).

The NSFR was developed to provide a sustainable maturity structure of assets and liabilities, and emphasizes the importance of more stable and longer-term sources of funding that can help to prevent long-term liquidity crises. It is to be introduced on January 1st, 2018 and is expected to have significant impact on the current banking system. The NSFR and its determinants is the focus of the present work.

$$
\text { NSFR }=\frac{\text { Available amount of stable funding }}{\text { Required amount of stable funding }} \geq 100 \% .
$$

The NSFR is a microprudential regulation designed to minimize liquidity crises by giving banks at the entity-level certain incentives to favor assets and liabilities that are less risk-averse. Its main aim is to address the problem of long-term less-liquid assets (i.e. loans) that are funded by short-term or less trustworthy sources. It can be defined as the available Amount of Stable Funding (ASF) over required stable funding (RSF), with banks being required to meet a minimum of $100 \%$ regulatory ratio.

ASF is a part of bank's funding available for over one year. The required stable funding (RSF) is part of bank's assets and off-balance sheet exposures considered illiquid for over one year, and needs to be support by stable funding. The aim of the NSFR is to lower the probability of a liquidity run and to support an institution undergoing funding difficulties for at least one year.

The amount of RSF is calculated by measuring the value of a bank's assets in the certain category. "The amount assigned to each category is then multiplied by its associated RSF factor and the total RSF is the sum of the weighted amounts added to the amount of OBS activity (or potential liquidity exposure) multiplied by its associated RSF factor." (BCBS 271; 2014)

\section{Empirical Analysis}

\subsection{Methodology}

First, NSFR for the 8300 European banks was calculated using the BCBS (2014) methodology. Subsequently, in order to identify determinants of the new liquidity framework for European banks proposed under Basel III, empirical analysis of panel data was used.

\subsection{Construction of the Dependent Variable: NSFR}

As described in the previous section, the NSFR regulatory ratio is composed of a numerator (ASF) and a denominator (RSF). To represent the stability of funding for liability items and the liquidity of asset items the weights of available stable funding and required stable funding range from $100 \%$ to $0 \%$. A higher numerator (available stable funding) shows more stable funding. For instance, regulatory capital has a $100 \%$ ASF factor, meanwhile "stable non-maturity (demand) deposits and term deposits with residual maturity of less than one year provided by retail and small business customers" have a $95 \%$ ASF factor. Liabilities without a stated maturity and "Trade date" payables arising from 
purchases of financial instruments, foreign currencies and commodities have a 0 percent ASF. Appendix A contains a summary of liability categories and associated ASF factors. In the same way, liquid assets have lower RSF weight, and illiquid assets have a higher RSF weight. Coins and banknotes immediately available to meet obligations, like all central bank reserves, have a $0 \%$ RSF factor. Conversely, all assets that are "encumbered for a period of one year or more", non-performing loans, loans to financial institutions with a residual maturity of one year or more, non-exchange-traded equities, fixed assets etc. are assigned a $100 \%$ RSF factor. These include, for example, all loans to financial institutions and central banks with residual maturity of between six months and less than one year; and "deposits held at other financial institutions for operational purposes", categories with a residual maturity of less than one year, including "loans to non-financial corporate clients, loans to retail customers (i.e. natural persons) and small business customers, and loans to sovereigns and PSEs." (BCBS; 2014). For further details, Appendix B summarizes the specific types of assets assigned to each category and their associated RSF factor, and Appendix C presents off-balance sheet categories and associated RSF factors.

\subsection{Econometric Estimation}

The dependent variables and the independent variable NSFR used in the regression analysis are shown in Table1 .

Table 1. Variables and sources of the data

\begin{tabular}{|c|c|c|}
\hline \multicolumn{3}{|l|}{ List of bank specific variables: } \\
\hline Concept & Variable & Source \\
\hline Net Stable Funding Ratio & NSFR & $\begin{array}{l}\text { Author's calculation based on BankScope } \\
\text { (Bureau van Dijk), BCBS methodology, } \\
\text { European Banking Federation }\end{array}$ \\
\hline LOG(Total Assets) & Size & $\begin{array}{l}\text { Author's calculation based on BankScope } \\
\text { (Bureau van Dijk) }\end{array}$ \\
\hline Loans / Customer Deposits \% & LOAN_DEP & BankScope (Bureau van Dijk) \\
\hline Interbank Assets / Interbank Liabilities \% & INTERB & BankScope (Bureau van Dijk) \\
\hline Cost To Income Ratio \% & COST_INC & BankScope (Bureau van Dijk) \\
\hline Total Regulatory Capital Ratio \% & CAR & BankScope (Bureau van Dijk) \\
\hline Return on Average Assets (ROAA) \% & ROA & BankScope (Bureau van Dijk) \\
\hline Non-Interest Expense / Average Assets\% & NOINT_EXP & BankScope (Bureau van Dijk) \\
\hline $\begin{array}{l}\text { Bank Failure (Moody's bank financial strength } \\
\text { rating, Basel capital, State) }\end{array}$ & BANKRUPT & $\begin{array}{l}\text { Author's calculation based on BankScope } \\
\text { (Bureau van Dijk) }\end{array}$ \\
\hline \multicolumn{3}{|l|}{ Monetary Policy Variables } \\
\hline Demand for central bank liquidity & ECB_LENDING & Euro Crisi Monitor \\
\hline \multicolumn{3}{|l|}{ Dummy Variables } \\
\hline $\begin{array}{l}\text { Specialization: commercial, cooperative, } \\
\text { savings, Bank Holding \& Holding Companies } \\
\text { are coded as } 1 \text {, and others } 0 .\end{array}$ & $S P E C$ & $\begin{array}{l}\text { Author's calculation based on BankScope } \\
\text { (Bureau van Dijk) }\end{array}$ \\
\hline $\begin{array}{l}\text { Variables linked to the listed or non listed } \\
\text { aspect. Listed }=1 \text {, non listed }=0 \text {. }\end{array}$ & LISTED & $\begin{array}{l}\text { Author's calculation based on BankScope } \\
\text { (Bureau van Dijk) }\end{array}$ \\
\hline Internationally active entity $=1$, local $=0$ & INTERN & $\begin{array}{l}\text { Author's calculation based on BankScope } \\
\text { (Bureau van Dijk) }\end{array}$ \\
\hline $\begin{array}{l}\text { Variable that is equal to } 1 \text { during } 2006-2007 \\
\text { and others } 0 \text {. }\end{array}$ & CRISIS & Author's calculation \\
\hline $\begin{array}{l}\text { if } \text { Entity_type ='Controlled subs.' then } \\
\text { Control=1; else Control=0; }\end{array}$ & CONTROL & $\begin{array}{l}\text { Author's calculation based on BankScope } \\
\text { (Bureau van Dijk) }\end{array}$ \\
\hline
\end{tabular}

Listed - unlisted distribution is shown in the Table 2.

Table 2. Percentage of number, bank total assets of listed and unlisted banks

\begin{tabular}{|c|c|c|}
\hline Listed_unlisted_delisted & Numbers (\%) & Assets (\%) \\
\hline Delisted & $2,08 \%$ & $8 \%$ \\
Listed & $3,82 \%$ & $37 \%$ \\
Unlisted & $94,10 \%$ & $55 \%$ \\
\hline & $\mathbf{1 0 0 \%}$ & $\mathbf{1 0 0 \%}$ \\
\hline
\end{tabular}

Country distribution is shown in Figure 1.

The sample contains data for following European countries: Austria, Belgium, Cyprus, Denmark, Finland, France, Germany, Greece, Iceland, Ireland, Italy, Luxembourg, Netherlands, Norway, Portugal, Spain, Sweden, Switzerland, 
United Kingdom. The analysis was first conducted for the Eurozone banks in order to consider ECB policies and features of the Eurozone market. It was then conducted for non-Eurozone countries.

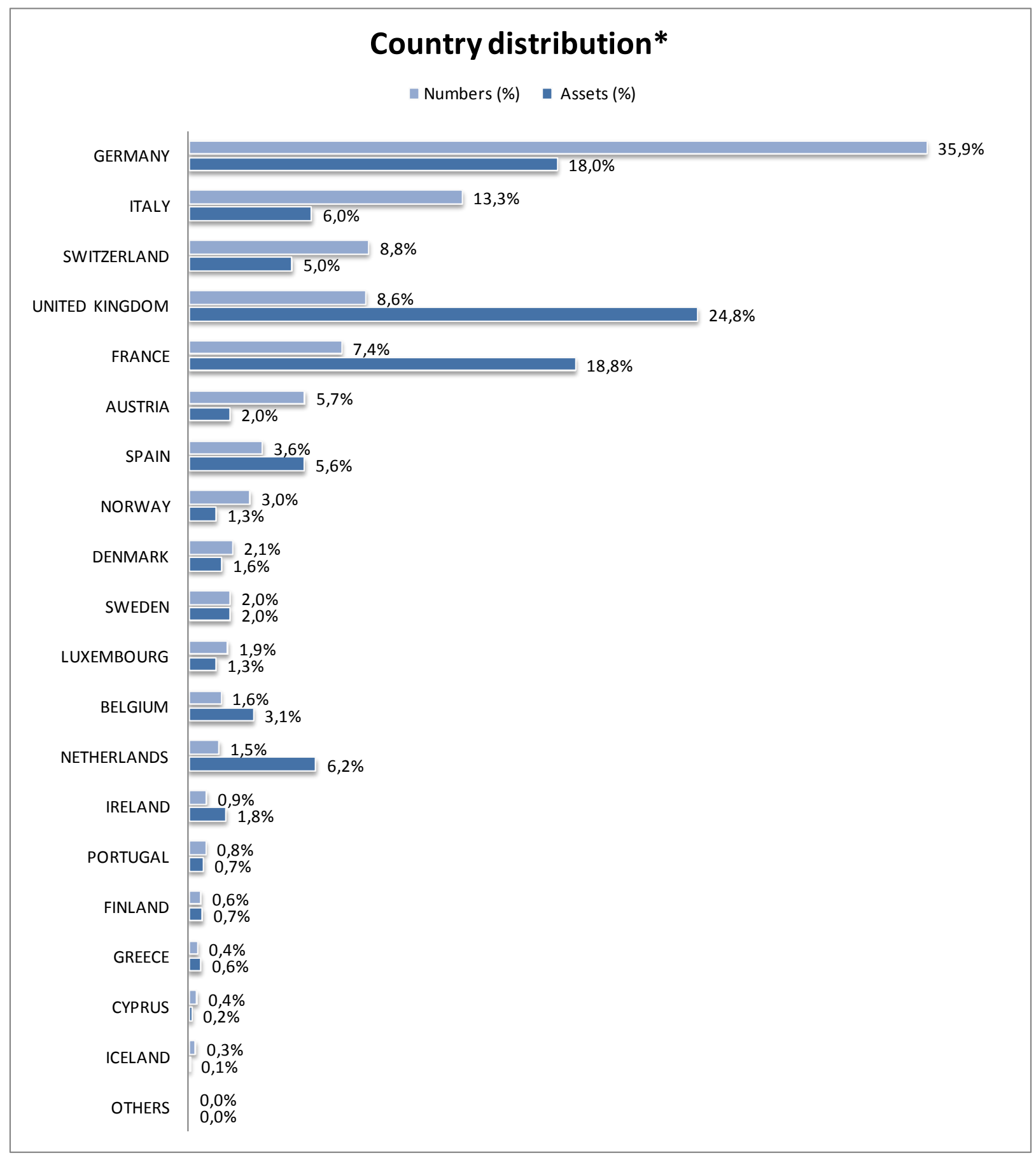

Figure 1. Country distribution

* All Sample Countries. Source: Bankscope

Figure 2 shows different types of bank, with percentages in terms of number per type of bank and total assets. 


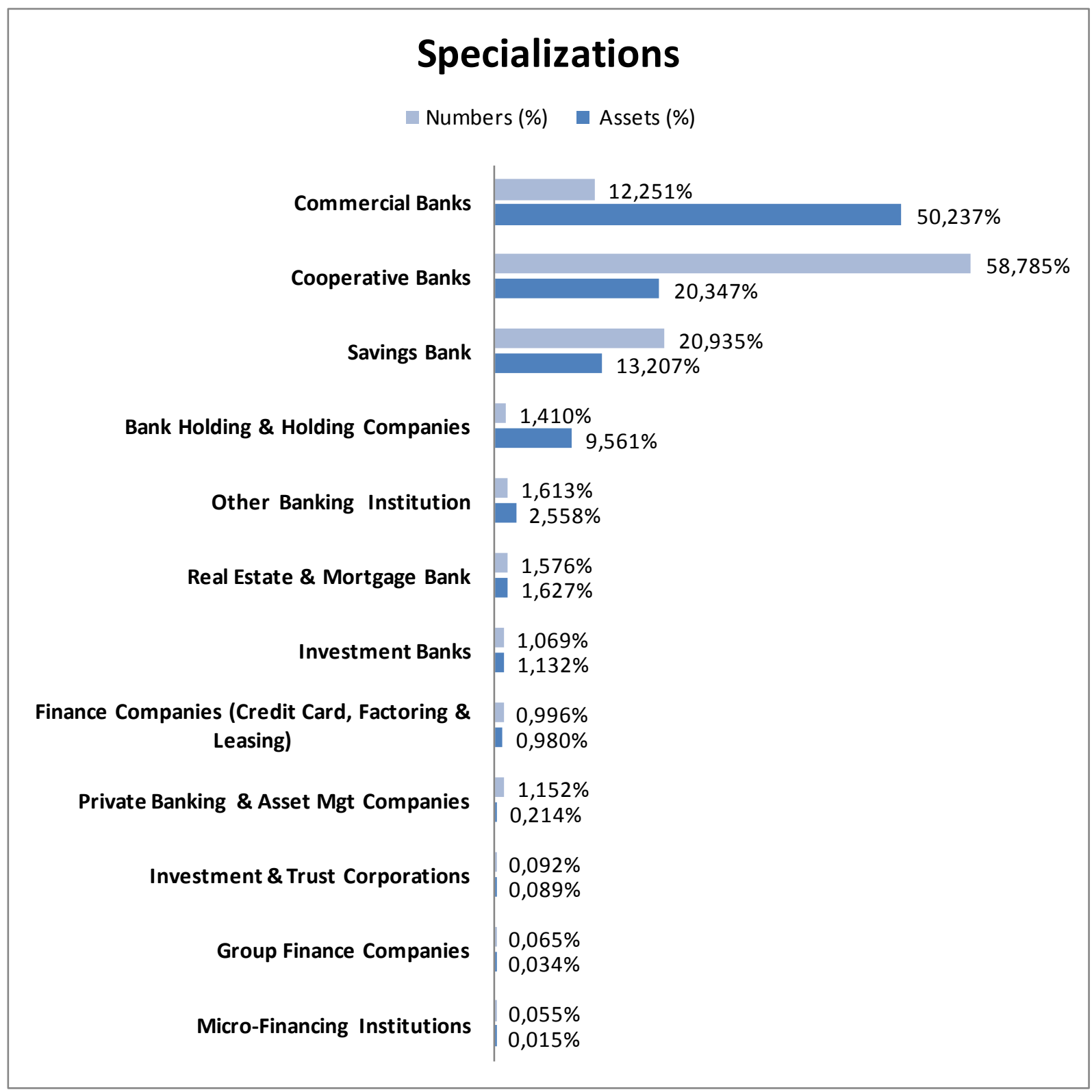

Figure 2. Specializations ( Distribution of Entities)

Source: Bankscope

The Hausman Test was performed on data to determine the appropriate method. This test does not reject the null hypothesis in favor of the random effect model. There is no random effect in these panel data. The $\mathrm{F}$ test was then performed and showed that the data satisfy the fixed-effects assumptions. The $\mathrm{F}$ test rejects the null hypothesis of no fixed time effect $(\mathrm{F}=6.12, \mathrm{p}<.0001)$. That is, there is a fixed time effect in these panel data. The fixed effect regression method is thus used to analyze full sample of European banks.

$$
\mathrm{L}_{\mathrm{it}}=\alpha+\beta^{\prime} \cdot X_{i t}+\delta_{i}+\varepsilon_{i t}
$$

Where $\mathrm{L}_{\mathrm{it}}$ is Liquidity ratio (NSFR) for bank $\mathrm{i}$ in time $\mathrm{t}, \mathrm{X}_{\mathrm{it}}=$ vector of explanatory variables for bank $\mathrm{i}$ in time $\mathrm{t}, \alpha=$ constant, $\beta^{\prime}=$ coefficient, $\delta_{\mathrm{i}}=$ fixed effects in bank $\mathrm{i}, \varepsilon_{\mathrm{i}}=$ error term

OLS regression was used for each single country.

\subsection{Data Overview and Economic Implications}

The dependent variable is the Net Stable Funding Ratio (NSFR) for the banks of the Euro area countries for the period 2006 - 2013. 


\section{Independent variables}

Bank failure (BANKRUPT). The main methodological approach consists of three steps. First, the BankScope database is evaluated and banks that are labeled as "bankrupt," "dissolved" (by liquidation or merger), "in liquidation", or "under receivership" are selected. Second, the Basel capital ratio (CAR) is measured for each bank, and banks having CAR lower than $8 \%$ between 2008 and 2009 are selected. Finally, banks categorized as "in distress" with rating E+ or E in Moody's bank financial strength rating are selected.

This method of selection is helpful in identifying banks, which are typically smaller and non-systematically important, which failed and underwent a process of resolution.(IMF; 2012)

Demand for central bank liquidity. The NSFR influences the demand for central bank liquidity only when refinancing tools are longer than one year, so banks may decide to increase their long term funding and reduce their short term funding. But where there is a structural liquidity deficit, demand will not go down, and banks will thus prefer refinancing operations over one year. This will raise ASF, and at the same time, the amount of encumbered assets. NSFR is therefore positively related to demand for central bank liquidity, though collateral effects of RSF pledged with the central bank should be considered.

Specialization (SPEC). Business models of bank differ in the way they treat liability and have different NSFR impact. For instance, investment banks have limited access to retail deposits and largely rely on wholesale funding and will be heavily hit by the new liquidity standard (Credit Suisse, 2012). Retail banks on the other hand have better access to stable funding and consequently have more favorable funding in terms of NSFR.

Interbank ratio (INTERB). The positive relationship is consistent with the fact that the proportion of the interbank assets to interbank liabilities can reveal the level of bank's liquidity in the interbank market. In fact, where there are problems on interbank markets relating to a high interbank risk premium, the number of interbank market transactions decrease and banks with liquidity shortage face more difficulty in finding a lender (see Hlebik, Verga 2015).

Total capital ratio (CAR). Banks with higher risk exposures seek to ensure their solvency by availability of an adequate amount of capital. In general, the minimum capital requirement serves to lower the risk of insolvency and at the same time helps banks to continue to play their role as intermediary necessary for economic progress. In fact 'risk absorption' theory is that higher capital facilitates liquidity creation. This is supported by Diamond et. (1983) and Allen et. (2004), who explore the interaction between liquidity creation and risk exposure of banks. Banks are generally prone to higher losses when they have greater liquidity needs. In this scenario, illiquid assets can be sold off at available rather than desirable market prices. Nevertheless, Bhattacharya et. (1993) and Coval et. (2005) point out that in such cases capital absorption can alleviate predisposition to risks and make banks more risk resilient in general. Further, Repullo (2004) demonstrates that shock absorption is more effective when the bank has higher capital adequacy. These studies all indicate that there is significant link between higher capital ratios and bank's ability to generate liquidity. Bank liquidity is under less stress where there is a higher endowment of capital.

Loan-to-deposit ratio (LOAN_DEP). The present analysis shows a negative relation between NSFR and the loan to deposit ratio. The indicator considers the proportion of illiquid loans (assets) on liquid liabilities, and thus expresses a lending institution's ability to cover withdrawals made by its customers. The NSFR implies that loans with residual maturity below one year should be financed by stable funding, which entails increasing the cost of loans. In fact, the NSFR is calibrated under the assumption that "short-term (maturing in less than one year) deposits provided by retail customers and funding provided by small business customers are behaviorally more stable than wholesale funding of the same maturity from other counterparties" (BCBS; 2014 ).

Profitability (ROA). The new liquidity framework will affect banks' behavior, and which implies a negative relationship with profitability. For example, in order to comply with the Net Stable Funding Ratio, banks are expected to lengthen average maturity and replace short-term with longer term funding. Because of term premia, this will increase their costs, and thus lower profitability.

SIZE (natural logarithm of total assets). NSFR is negatively related to bank size. Delechatet (2012) advises small banks to obtain more liquidity if they are financially limited. Based on a substantial sample of US banks, Kashyap et al. (2002) concludes that there is a direct link between bank size and the amount of liquid assets that it holds. Smaller banks are considered to be more liquid since their access to capital markets is more limited

Cost Income Ratio (COST_INC) determines operating costs as a percentage of operating income. The negative relationship between this ratio and the NSFR shows that less efficient banks have more difficulties in meeting new requirements.

Non-Interest Expense ratio (Noint_exp) is calculated by annualizing fixed operating costs incurred by a financial institution; salaries and employee benefits, running costs, costs of fixed assets, and other non-interest expenses, 
divided by average assets. A positive relationship between this ratio and NSFR indicates that banks more successful in reaching the Basel III liquidity requirements (NSFR) spend more resources on HR and invest in information systems which reduce data processing costs. This spending is crucial for the procurement and retention of competent specialists.

\section{Conclusion}

Stable systemic liquidity conditions are vital for the financial sector and macroeconomic stability. Liquidity is a systemic and fundamental notion and deviation from appropriate levels of availability can lead to a systemic financial crises.

The results of our empirical analysis provide the following conclusions. There are significant and positive relationships between liquidity and capital adequacy of banks. The liquidity indicator increases with the Non-Interest Expense to Average Assets indicator, although the impact and the dynamics are different across European banks. For instance, holding all other variables constant, on average, for every one percent increase in this ratio, the increase in the NSFR is bigger for France $(+0.073 \%)$, Italy $(+0.051 \%)$ and Spain $(+0.045 \%)$ and it impacts to a lesser extent for Germany $(+0.019 \%)$.

Our analysis also indicates that net stable funding ratio is negatively related to bank size, but positively related to interbank ratio. As is often said, large banks are "too big to fail" and have no difficulty borrowing money on the interbank market or finding support from Central banks. Smaller banks however are more likely to have a 'cushion' of liquid assets. Liquidity tightening importantly tends to indicate the presence of underlying bank weaknesses which need to be interpreted.

ECB lending has a positive impact on NSFR. In turn, loan-to-deposit ratio, ROA as well as bankruptcy are negatively related to NSFR. It is clear that the regulation of liquidity risk will have a noticeable impact on the way banks operate. Furthermore, the liquidity standards will influence money markets, as well as transmission mechanisms of monetary policy, and central banks will be required to carefully consider these aspects once the new Basel standard comes into force.

The NSFR is one of the key aspects of the review of the Capital Requirements Directives for the financial services industry and it raises several issues in terms of cost and benefit. Further consideration is required concerning the asymmetrical treatment of repos and reverse repos, cash/non cash collateral, derivatives and coherence the Stable Funding Ratio with short-term liquidity coverage ratio (LCR).

\section{References}

Allen, F., \& Douglas, G. (2004). Competition and Financial. Journal of Money, Credit and Banking, 36. https://doi.org/10.1353/mcb.2004.0038

Amihud, Y., Mendelson, H., \& Pedersen, L. (2013). Market liquidity. asset Pricing, Risk and Crises. Cambridge university Press, Cambridge, 2013, 289.

Basel Committee on Banking Supervision. (2010). Basel III: International framework for liquidity risk measurement, standards and monitoring. Basel. Bank for International Settlements. Basel risk measurement, standards and monitoring. http://www.bis.org/publ/bcbs188.htm

Basel Committee on Banking Supervision. (2011). Basel III: A global regulatory framework for more resilient banks and banking systems; Bank for International Settlement.

Basel Committee on Banking Supervision. (2013). Basel III: The Liquidity Coverage Ratio and liquidity risk monitoring tools; Bank for International Settlement.

Basel Committee on Banking Supervision. (2014). Basel III: The Net Stable Funding Ratio. http://www.bis.org/publ/bcbs271.pdf

Basel Committee on Banking Supervision.Basel III: international regulatory framework for banks. http://www.bis.org/bcbs/basel3.htm

Bhattacharya, S., \& Gale, D. (1987). Preference Shocks, Liquidity and Central Bank Policy. William Barnett and Kenneth Singleton, eds.: New Approaches to Monetary Economics, Cambridge University Press, New York.

Coval, J. D., \& Thakor, A. V. (2005). Financial Intermediation as a Beliefs-bridge between Optimists and Pessimists. Journal of Financial Economics, 75, 535-569. https://doi.org/10.1016/j.jfineco.2004.02.005

Delechat, C., Camila, H., Muthoor, P., \& Vtyurina, S. (2012). The Determinants of Banks' Liquidity Buffers in Central America, IMF. Working Paper Series WP/12/301.

Diamond, D. (2007). Banks and Liquidity Creation: A Simple Exposition of the Diamond-Dybvig Model. Federal Reserve Bank of Richmond Economic Quarterly, Spring 2007, 93(2), 189-200. 
Diamond, D., \& Rajan, R. (2005). Liquidity shortages and banking crises. The journal of finance, 60(2). https://doi.org/10.1111/j.1540-6261.2005.00741.x

Diamond, D., \& Dybvig, P. (1983). Bank Runs, Deposit Insurance, and Liquidity. Journal of Political Economy, 91(3), 401-419. https://doi.org/10.1086/261155

Dietrich, A., \& Wanzenried, G. (2014). The determinants of commercial banking profitability in low-, middle-, and high-income countries. The Quarterly Review of Economics and Finance, 22, 1-18.

Hong, H., Huang, J. Z., \& Wu, D. (2014). The information content of Basel III liquidity risk measures. Journal of Financial Stability, 15, 91-111. https://doi.org/10.1016/j.jfs.2014.09.003

Hull, J. C. (2015). Risk management and financial institutions, Wiley finance series, 2015- Fourth Edition (textbook).

IMF. (2008). Global Financial Stability Report: Containing Systemic Risks and Restoring Financial Soundness, Monetary and Capital Markets Department. https://www.imf.org/en/Publications/GFSR/Issues/2016/12/31/Global-Financial-Stability-Report-April-2008-Conta ining-Systemic-Risks-and-Restoring-21707

Kashyap, A. K., Rajan, R., \& Stein, J. C. (2002). Banks as liquidity providers: An explanation for the coexistence of lending and deposit - taking. The Journal of Finance, 57(1), 33-73. https://doi.org/10.1111/1540-6261.00415

Morris, S., \& Shin, H. S. (2004). "Liquidity Black Holes". Review of Finance, 8(March), 1-18. https://doi.org/10.1023/B:EUFI.0000022155.98681.25

Persaud, A. D. (2003). Liquidity black holes. Journal of Political Economy, 111, 642-685.

Repullo, R. (2004). Capital requirements, market power, and risk-taking in banking. Journal of Financial Intermediation, 13(2), 156-182. https://doi.org/10.1016/j.jfi.2003.08.005

Treepongkaruna, S., \& Bissoondoyal, B. E. (2011). An analysis of the determinants of bank ratings: comparison across ratings agencies. Australian Journal of Management, 36(3), 405-424. https://doi.org/10.1177/0312896211426676

Vazquez, F., \& Federico, P. (2012). Bank Funding Structures and Risk: Evidence from the Global Financial Crisis; IMF working paper; European Department.

Vodová, P. (2013). Determinants which affect liquid asset ratio of Czech and Slovak Commercial; Silesian University in Opava; School of Business Administration in Karvina.

\section{Appendix A}

Summary of liability categories and associated ASF factors

\begin{tabular}{l|l}
\hline $\begin{array}{l}\text { ASF } \\
\text { factor }\end{array}$ & Components of ASF category \\
\hline $100 \%$ & $\begin{array}{l}\text { - Total regulatory capital (excluding Tier 2 instruments with residual maturity of less than one year) } \\
\text { - Other capital instruments and liabilities with effective residual maturity of one year or more }\end{array}$ \\
\hline $95 \%$ & $\begin{array}{l}\text { - Stable non-maturity (demand) deposits and term deposits with residual maturity of less than one year } \\
\text { provided by retail and small business customers }\end{array}$ \\
\hline $90 \%$ & $\begin{array}{l}\text { - Less stable non-maturity deposits and term deposits with residual maturity of less than one year provided by } \\
\text { retail and small business customers }\end{array}$ \\
\hline $\begin{array}{l}\text { - Funding with residual maturity of less than one year provided by non-financial corporate customers } \\
\text { - Operational deposits } \\
\text { - Funding with residual maturity of less than one year from sovereigns, PSEs, and multilateral and national } \\
\text { development banks } \\
\text { - Other funding with residual maturity between six months and less than one year not included in the above } \\
\text { categories, including funding provided by central banks and financial institutions }\end{array}$ \\
\hline $\begin{array}{l}\text { - All other liabilities and equity not included in the above categories, including liabilities without a stated } \\
\text { maturity (with a specific treatment for deferred tax liabilities and minority interests) } \\
\text { - NSFR derivative liabilities net of NSFR derivative assets if NSFR derivative liabilities are greater than } \\
\text { NSFR derivative assets } \\
\text { " TTrade date" payables arising from purchases of financial instruments, foreign currencies and commodities }\end{array}$ \\
\hline
\end{tabular}




\section{Appendix B}

Summary of asset categories and associated RSF factors

\begin{tabular}{|c|c|}
\hline $\begin{array}{l}\text { RSF } \\
\text { factor }\end{array}$ & Components of RSF category \\
\hline $0 \%$ & $\begin{array}{l}\text { - Coins and banknotes } \\
\text { - All central bank reserves } \\
\text { - All claims on central banks with residual maturities of less than six months } \\
\text { - "Trade date" receivables arising from sales of financial instruments, foreign currencies and commodities. }\end{array}$ \\
\hline $5 \%$ & - Unencumbered Level 1 assets, excluding coins, banknotes and central bank reserves \\
\hline $10 \%$ & $\begin{array}{l}\text { - Unencumbered loans to financial institutions with residual maturities of less than six months, where the loan } \\
\text { is secured against Level } 1 \text { assets as defined in LCR paragraph 50, and where the bank has the ability to freely } \\
\text { rehypothecate the received collateral for the life of the loan }\end{array}$ \\
\hline $15 \%$ & $\begin{array}{l}\text { - All other unencumbered loans to financial institutions with residual maturities of less than six months not } \\
\text { included in the above categories } \\
\text { - Unencumbered Level } 2 \mathrm{~A} \text { assets }\end{array}$ \\
\hline $50 \%$ & $\begin{array}{l}\text { - Unencumbered Level } 2 \mathrm{~B} \text { assets } \\
\text { - HQLA encumbered for a period of six months or more and less than one year } \\
\text { - Loans to financial institutions and central banks with residual maturities between six months and less than one } \\
\text { year } \\
\text { - Deposits held at other financial institutions for operational purposes } \\
\text { - All other assets not included in the above categories with residual maturity of less than one year, including } \\
\text { loans to non-financial corporate clients, loans to retail and small business customers, and loans to sovereigns } \\
\text { and PSEs }\end{array}$ \\
\hline $65 \%$ & $\begin{array}{l}\text { - Unencumbered residential mortgages with a residual maturity of one year or more and with a risk weight of } \\
\text { less than or equal to } 35 \% \text { under the Standardised Approach } \\
\text { - Other unencumbered loans not included in the above categories, excluding loans to financial institutions, with } \\
\text { a residual maturity of one year or more and with a risk weight of less than or equal to } 35 \% \text { under the } \\
\text { standardised approach }\end{array}$ \\
\hline $85 \%$ & $\begin{array}{l}\text { - Cash, securities or other assets posted as initial margin for derivative contracts and cash or other assets } \\
\text { provided to contribute to the default fund of a CCP } \\
\text { - Other unencumbered performing loans with risk weights greater than } 35 \% \text { under the standardised approach } \\
\text { and residual maturities of one year or more, excluding loans to financial institutions } \\
\text { - Unencumbered securities that are not in default and do not qualify as HQLA with a remaining maturity of one } \\
\text { year or more and exchange-traded equities } \\
\text { - Physicaltradedcommodities, includinggold }\end{array}$ \\
\hline $100 \%$ & $\begin{array}{l}\text { - All assets that are encumbered for a period of one year or more } \\
\text { - NSFR derivative assets net of NSFR derivative liabilities if NSFR derivative assets are greater than NSFR } \\
\text { derivative liabilities } \\
\text { - } 20 \% \text { of derivative liabilities as calculated according to paragraph } 19 \\
\text { - All other assets not included in the above categories, including non-performing loans, loans to financial } \\
\text { institutions with a residual maturity of one year or more, non-exchange-traded equities, fixed assets, items } \\
\text { deducted from regulatory capital, retained interest, insurance assets, subsidiary interests and defaulted } \\
\text { securities. }\end{array}$ \\
\hline
\end{tabular}

\section{Appendix C}

Summary of off-balance sheet categories and associated RSF factors

\begin{tabular}{l|l}
\hline RSF factor & RSF category \\
\hline $5 \%$ of the currently undrawn portion & $\begin{array}{l}\text { Irrevocable and conditionally revocable credit and liquidity facilities to } \\
\text { any client }\end{array}$ \\
\hline & $\begin{array}{l}\text { Other contingent funding obligations, including products and instruments } \\
\text { such as: } \\
\text { - Unconditionally revocable credit and liquidity facilities } \\
\text { - Trade finance-related obligations (including guarantees and letters of } \\
\text { credit) } \\
\text { - Guarantees and letters of credit unrelated to trade finance obligations } \\
\text { - Non-contractual obligations such as: } \\
\text { - potential requests for debt repurchases of the bank's own debt or that of } \\
\text { related conduits, securities investment vehicles and other such financing } \\
\text { facilities } \\
\text { factors based on their national } \\
\text { circumstances }\end{array}$ \\
$\begin{array}{l}\text { such as adjustable rate notes and variable rate demand notes (VRDNs) } \\
\text { s. managed funds that are marketed with the objective of maintaining a } \\
\text { stable value }\end{array}$
\end{tabular}




\section{Appendix D}

The fixed effect regression method

\section{All Eurozone countries:}

$$
\begin{aligned}
& \text { Dependent Variable: NSFR., } \\
& \text { Analysis of variance. } \\
& \begin{array}{lrrrrr} 
& & \text { Sum of } & \text { Mean.l } & & \\
\text { Source } & \text { DF } & \text { Squares } & \text { Square } & \mathrm{F} \text { value } & \mathrm{Pr}>\mathrm{F} . \text {. } \\
\text { Model } & 12 & 800.67552 & 66.72296 & 1525.37 & <.0001 .1
\end{array} \\
& \begin{array}{ccc} 
& \text { Parameter Standard. } & \\
\text { Variable Estimate } & \text { Error Type II SS F Value } \mathrm{Pr}>\mathrm{F} \text {. }
\end{array} \\
& \text { Intercept } \quad 1.46791 \quad 0.02649 \quad 134.32688 \quad 3070.87<.0001 \text {. } \\
& \begin{array}{llllll}
\text { CONTROL } & 0.04877 & 0.08725 & 1.97848 \quad 45.23 & <.8001
\end{array} \\
& \begin{array}{llllll}
\text { SPEC } & -0.04433 \quad 0.01118 \quad 0.68715 \quad 15.71<.0001
\end{array} \\
& \begin{array}{llllll}
\text { SIZE } & -0.02173 & 0.00130 & 12.26415 & 280.37 & <.0001 \text {. }
\end{array} \\
& \text { LOAN_DEP } \quad-0.00320 \quad 0.00003440 \quad 378.60572 \quad 8655.38<.0001 \text {. } \\
& \begin{array}{lllllll}
\text { INTERB } \quad 0.00052017 & 0.00001427 & 58.08360 & 1327.86 & <.0001 .
\end{array} \\
& \begin{array}{llllll}
\text { CAR } & 0.00477 & 0.00028932 & 11.88056 & 271.60<.0001 .1
\end{array} \\
& \text { NOINT_EXP } \quad 0.80831 \quad 0.00134 \quad 1.67219 \quad 38.23<.0801 . \\
& \text { GDP } \quad 0.00861 \quad 0.00057180 \quad 9.92190 \quad 226.83<.0001 . \\
& \begin{array}{llllll}
\text { COST_INC } & -0.00025785 & 0.00012597 & 0.18327 & 4.19 & 0.0407 .
\end{array} \\
& \text { ROA }-0.02194 \quad 0.00270 \quad 2.87931 \quad 65.82<.0001 \text {. } \\
& \begin{array}{lllllll}
\text { BANKRUPT } & -0.04949 & 0.01904 & 0.29561 & 6.76 & 0.0093 .1
\end{array} \\
& \text { ECB_LENDING } \quad 3.965273 E-7 \quad 2.738716 E-8 \quad 9.16965 \quad 209.63<.0001 \text {. }
\end{aligned}
$$

\begin{tabular}{|c|c|c|c|c|c|c|}
\hline Variable & Label & $\mathrm{N}$ & Mean & Std Dev & Minimum & Maximum \\
\hline$f f f f f f f f f f f$ & $f f f f f f f f f f f$ & $f f f f f$ & $f f f f f f f f f f f f f$ & $f f f f f f f f f f f f$ & $f f f f f f f f f f f f$ & $f f f f f f f f f f f$ \\
\hline NSFR_perc & & 8293 & 102.1509177 & 30.9652741 & 36.0706250 & 309.444417 \\
\hline intern & INTERNATIONAL & 8293 & 0.0307488 & 0.1726468 & 0 & 1.00000 \\
\hline listed & LISTED & 8293 & 0.0274931 & 0.1635250 & 0 & 1.00000 \\
\hline CONTROL & CONTROLLED & 8293 & 0.0900760 & 0.2863078 & 0 & 1.000000 \\
\hline SPEC & SPECIALIZATION & 8293 & 0.9776920 & 0.1476921 & 0 & 1.000000 \\
\hline SIZE & SIZE & 8293 & 13.4877740 & 1.8093631 & 9.5104450 & 21.6153106 \\
\hline LOAN_DEP & LOAN_DEP & 8293 & 96.7072037 & 43.2834836 & 0.0400000 & 302.2100000 \\
\hline INTERB & INTERB & 8293 & 134.8874460 & 145.8564347 & 9.5300000 & 896.970000 \\
\hline CAR & CAR & 8293 & 16.2351947 & 4.6275006 & 9.9500000 & 45.150000 \\
\hline NOINT_EXP & NOINT_EXP & 8293 & 2.2782154 & 0.6869544 & 0 & $11.71000 e$ \\
\hline GDP & GDP & 8293 & 0.2645002 & 3.8135601 & -14.2000000 & 6.500000 \\
\hline COST_INC & COST_INC & 8293 & 68.1766592 & 10.4770485 & 8.6210000 & 142.621000 \\
\hline ROA & ROA & 8293 & 0.3413857 & 0.3103225 & -0.1570000 & 3.817000 \\
\hline BANKRUPT & BANKRUPT & 8293 & 0.0063909 & 0.0796922 & 0 & 1.0000000 \\
\hline
\end{tabular}

R-Square $=0.6500$ and $\mathrm{C}(\mathrm{p})=13.6279$

Eurozone complete sample. Descriptive statistics

The MEANS Procedure

The table below shows the case where specializations that do not belong to the target population were removed from the original data. 


\section{Non - Eurozone countries:}

\begin{tabular}{|c|c|c|c|c|}
\hline \multicolumn{5}{|c|}{$\begin{array}{l}\text { Dependent Variable: NSFR ., } \\
\text { Analysis of variance. }\end{array}$} \\
\hline \multirow[b]{2}{*}{ Source } & & Sum of & Mean.. & \\
\hline & DF & Squares & Square & F value \\
\hline \multirow{2}{*}{ Model } & 12 & 800.67552 & 66.72296 & 1525.37 \\
\hline & Parameter & standard. & & \\
\hline Variable & Estimate & Error & Type II ss & $\mathrm{F}$ value $\mathrm{Pr}>\mathrm{F} .1$ \\
\hline Intercept & 1.46791 & 0.02649 & 134.32688 & $3070.87<.0001$ \\
\hline CONTROL & 0.84877 & 0.00725 & 1.97840 & $45.23<.0001$ \\
\hline SPEC & -0.04433 & 0.01118 & 0.68715 & $15.71<.8001$. \\
\hline SIZE & -0.02173 & 0.00130 & 12.26415 & $280.37<.0801$. \\
\hline LOAN_DEP & -0.00320 & 0.00003440 & 378.60572 & $8655.38<.0001$ \\
\hline INTERB & 0.60052017 & 0.60001427 & 58.08360 & $1327.86<.0001$. \\
\hline CAR & 0.00477 & 0.00028932 & 11.88056 & $271.60<.0001$. \\
\hline NOINT_EXP & 0.00831 & 0.00134 & 1.67219 & $38.23<.0001$. \\
\hline GDP & 0.80861 & 0.00057180 & 9.92190 & $226.83<.0001$. \\
\hline COST_INC & -0.00025785 & 0.00012597 & 0.18327 & $4.19 \quad 0.0407$ \\
\hline $\mathrm{ROA}$ & -0.02194 & 0.80270 & 2.87931 & $65.82<.8001 .1$ \\
\hline BANKRUPT & -0.04949 & 0.01904 & 0.29561 & $6.76 \quad 0.0093$. \\
\hline ECB_LENDING & $3.965273 \mathrm{E}-7$ & $2.738716 \mathrm{E}-8$ & 9.16965 & $209.63<.0001$. \\
\hline
\end{tabular}

R-Square $=0.7041$ and $\mathrm{C}(\mathrm{p})=5.3079$

All variables left in the model are significant at the 0.1000 level.

Non-Eurozone descriptive statistics shown in Table 4.

The MEANS Procedure

\begin{tabular}{llcrrrr} 
Variable & Label & $\mathrm{N}$ & \multicolumn{1}{c}{ Mean } & \multicolumn{1}{c}{ Std Dev } & Minimum & Maximum \\
fffffffffffffffffffffffffffffffffffffffffffffffffffffffffffffffffffffffffffffffffffffffffffffffffffffffffff \\
NSFR_perc & & 708 & 84.2450955 & 31.7855776 & 36.0979704 & 286.3394188 \\
intern & INTERNATIONAL & 708 & 0.1553672 & 0.3625105 & 0 & 1.0000000 \\
listed & LISTED & 708 & 0.3192090 & 0.4664997 & 0 & 1.0000000 \\
CONTROL & CONTROLLED & 708 & 0.3177966 & 0.4659491 & 0 & 1.0000000 \\
SPEC & SPECIALIZATION & 708 & 0.8064972 & 0.3953229 & 0 & 1.0000000 \\
SIZE & SIZE & 708 & 15.4136663 & 2.4812596 & 11.3072751 & 21.6736493 \\
LOAN_DEP & LOAN_DEP & 708 & 116.2994915 & 39.7849104 & 4.8700000 & 271.3200000 \\
INTERB & INTERB & 708 & 118.6050989 & 149.0651393 & 9.4900000 & 870.4700000 \\
CAR & CAR & 708 & 16.2747316 & 4.2583057 & 9.9500000 & 44.3000000 \\
NOINT_EXP & NOINT_EXP & 708 & 2.1387147 & 1.6632975 & 0.3800000 & 15.1400000 \\
GDP & GDP & 708 & 0.6000000 & 3.4792169 & -14.7000000 & 9.7000000 \\
COST_INC & COST_INC & 708 & 60.8989986 & 14.6467974 & 22.5790000 & 149.6060000 \\
ROA & ROA & 708 & 0.7484124 & 0.6140283 & -0.1510000 & 3.7870000 \\
BANKRUPT & BANKRUPT & 708 & 0.0028249 & 0.0531118 & 0 & 1.0000000 \\
fffffffffffffffffffffffffffffffffffffffffffffffffffffffffffffffffffffffffffffffffffffffffffffffffffffffff
\end{tabular}

All missing values, outlier $<\%$ th and $>95$ th percentiles, as well as values that do not belong to the target population, were removed from the original data. 


\section{Results of the model for Germany, France, Italy, Spain:}

Dependent Variable: NSFR. $* * * / * * *$ refer to the coefficient significance at $10 \% / 5 \% / 1 \%$ level respectively.

\begin{tabular}{ccccc}
\hline Dependent Variable: & GERMANY & FRANCE & ITALY & SPAIN \\
\hline C & $1.41647 * * *$ & $1.52311 * * *$ & $0.92891 * * *$ & $0.87285 * * *$ \\
NSFR(-1) & $0.02382 * * *$ & $-0.09543 * * *$ & - & - \\
CONTROL & $0.06749 * * *$ & - & $0.04749 * * *$ & $0.04760 * * *$ \\
SIZE & $-0.01169 * * *$ & $-0.02304 *$ & - & - \\
LOAN_DEP & $-0.00409 * * *$ & $-0.00129 * * *$ & $-0.00223 * * *$ & $-0.00220^{* * *}$ \\
INTERB & $0.000855^{* * *}$ & $0.00055^{* *}$ & $0.000099 * * *$ & $0.0000957 * * *$ \\
COST_INC & $-0.000758^{* * *}$ & $-0.00261 * *$ & $-0.000953 * *$ & - \\
CAR & $0.00394 * * *$ & $-0.01435^{* *}$ & $0.00780^{* * *}$ & $0.00741 * * *$ \\
ROA & $-0.07257 * * *$ & $-0.15454 * *$ & - & $0.02213 * * *$ \\
NOINT_EXP & $0.01900 * * *$ & $0.07313 * * *$ & $0.05148 * * *$ & $0.04467 * * *$ \\
ECB_LENDING & $6.532 \mathrm{E}-8 * *$ & - & $2.695 \mathrm{E}-7 * * *$ & $3.1492 \mathrm{E}-7 * * *$ \\
BANKRUPT & - & - & $-0.04087 *$ & $-0.04017 *$ \\
SPEC & - & - & $-0.10444 * * *$ & $-0.10616^{* * *}$ \\
No. observations: & 6821 & 145 & 0.5274 & 1905 \\
R-square & 0.7322 & 0.4775 & & 0.5287
\end{tabular}

All variables left in the model are significant at the 0.1000 level

\section{Copyrights}

Copyright for this article is retained by the author(s), with first publication rights granted to the journal.

This is an open-access article distributed under the terms and conditions of the Creative Commons Attribution license which permits unrestricted use, distribution, and reproduction in any medium, provided the original work is properly cited. 